\title{
Hydration, microstructural characteristics and rheological properties of wheat dough enriched with zinc gluconate and resistant starch
}

\author{
Yueqi QIN ${ }^{1}$, Haiyan GAO $^{1 *}$ (D), Jie ZENG ${ }^{1}$, Yufen LIU1 ${ }^{1}$, Yunfei DAI ${ }^{1}$
}

\begin{abstract}
The aim of this work was to study the effect of zinc (Zn) gluconate-resistant potato starch type 2 (RS2) systems on hydration and rheological properties of wheat flour dough. Wheat flour, $\mathrm{Zn}$ with a content from $0.16 \mathrm{mg} \%$ to $0.32 \mathrm{mg} \%$ (flour basis), and enriched RS2 at levels of $10 \mathrm{~g} \%$ to $30 \mathrm{~g} \%$ (flour basis) were used. Hydration, rheological properties and microstructural characteristics of wheat flour dough were analyzed. The results showed that the dough stability time decreased with increasing RS2. When the RS2 content was less than $25 \mathrm{~g} \%$, the stability time was significantly higher than that of the control group. RS2 and $\mathrm{Zn}$ could improve the tensile strength and thermal stability of the dough but reduced the quality of protein and mechanical resistance of the dough. $\mathrm{Zn}$ could increase the hardness, adhesiveness and springiness of the dough, while RS2 had a negative effect on the springiness of the dough. The RS2-Zn system reduced the water absorption, moisture content and molecular mobility of the dough, and damaged the microstructure of the dough to varying degrees. The addition of RS2 (10 g\%) and $\mathrm{Zn}(0.24 \mathrm{mg} \%)$ could render a dough with satisfactory rheological properties, hydration and microstructural characteristics.
\end{abstract}

Keywords: wheat dough; zinc gluconate; resistant starch; rheological properties; microstructure.

Practical Application: Improvement the quality and nutrition of wheat dough by zinc gluconate-resistant potato starch.

\section{Introduction}

Resistant starch (RS) was wrapped by insoluble dietary fiber in the small intestine of the human body, so amylase cannot contact starch, and thus, it cannot be digested and absorbed (Englyst et al., 1992). Further studies in the field of enzyme resistance mechanisms have classified RS into five types: RS1-RS5 (Nugent, 2005). RS1 and RS2 naturally exist in fresh foods. The former is physically embedded starch, which is surrounded by a protein matrix and cell wall material to hinder the role of $a$-amylases. The latter is a compact crystal structure composed of amyloses, which hinders enzyme contact with the particles. RS3 is a RS formed by the thermal modification of RS1 or RS2. RS4 is a chemically modified starch. In RS5, the amylose-lipid complex forms a single helix structure, which hinders the combination of amylase and starch (Dupuis et al., 2014). As a functional substance of dietary fiber, RS cannot be digested and decomposed into glucose in the human stomach and small intestine. RS not only has a low calorie content, low digestibility and the ability to lower blood sugar but can also overcome the quality defects of traditional dietary fiber, such as the dark color, rough texture, small volume and poor taste (Fuentes-Zaragoza et al., 2010). When RS is added to flour products, the influence on the rheological properties of dough is directly related to the processing properties of staple food products (Nugent, 2005). RS2 is a natural raw material with a light taste, white color and fine particles. Compared with traditional fiber products, it has a high gelatinization temperature, good extrusion film forming performance and low water retention performance. It can provide better texture, appearance, and taste for low-volume high-fiber products compared to traditional high-fiber products (Sajilata et al., 2006).

Zinc (Zn) plays a vital role in many biological processes, such as enzyme action, cell membrane stabilization, gene expression, cell signaling, insulin action and carbohydrate metabolism (Poudel et al., 2017; Majdoub et al., 2020). According to the World Health Organization (2002), Zn deficiency affects one-third of the world's population and is a major factor affecting $1.4 \%$ of deaths worldwide, particularly in developing countries. It is well known that available $\mathrm{Zn}$ reserves in the human body decrease significantly with age, and thus, dietary $\mathrm{Zn}$ supplementation is recommended to prevent oxidative damage and reduce the risk of cancer (Mocchegiani et al., 2007). There is no functional or physical reserve of $\mathrm{Zn}$, and thus, adequate dietary $\mathrm{Zn}$ needs to be provided on a regular basis. The regular intake of small amounts of animal protein foods (such as red meat, poultry and fish) are readily available sources of dietary $\mathrm{Zn}$. Zn deficiency is mainly due to low dietary $\mathrm{Zn}$ content or bioavailability. $\mathrm{Zn}$ intake is mainly achieved through dietary supplements or fortified foods (Ranasinghe et al., 2015). Yonekura \& Suzuki (2005) investigated the effects of Zn, phytic acid and RS on Zn bioavailability in rats. It was found that RS could increase the flow of nonabsorbed $\mathrm{Zn}$ from the small intestine to the cecum, and the low $\mathrm{pH}$ produced 
by the fermentation of RS in the cecum promoted an increase in $\mathrm{Zn}$ bioavailability.

Previous studies have effectively explored the bioavailability of RS to $\mathrm{Zn}$. However, there is no information on the effect of adding $\mathrm{Zn}$ and RS mixtures on the rheological properties of wheat flour dough. Therefore, the purpose of this work is to study the effects of $\mathrm{Zn}$ and RS systems on the hydration and rheological properties of wheat flour dough. The doughs made with different additive amounts of RS and $\mathrm{Zn}$ were compared with doughs made without RS and $\mathrm{Zn}$ (control) by central composite design.

\section{Materials and methods}

\subsection{Materials}

Wheat flour (medium strength flour) was purchased from the Yihai Flour Industry Co., Ltd. (Henan, China). The moisture, protein and ash contents in flour were $14.06 \%, 18.34 \%$ and $0.38 \%$, respectively. Zinc (Zn) gluconate was obtained from the Henan Wanbang Industrial Co., Ltd. (Henan, China). Resistant potato starch type 2 (RS2, purity: $98 \%$ ) was obtained from the Guangdong Huasheng Food Co., Ltd. (Guangdong, China). Other chemical reagents were at least of analytical grade in all experiments.

\subsection{Experimental design}

Response surface methodology (RSM) was used to design the experiment and achieve the optimal response. Central composite design is an experimental design that can be used in RSM (Khuri \& Cornell, 1996). According to the central composite design, a mixture of wheat flour, $\mathrm{Zn}$ and RS2 was prepared. The amount of $\mathrm{Zn}$ added to the bread was chosen according to the maximum allowable $\mathrm{Zn}$ content in Commission Directive 2008/100/EC. The amount of RS2 used in flour depended on the silty characteristics of the flour used. The $\mathrm{Zn}(0.16 \mathrm{mg} \%$ to $0.32 \mathrm{mg} \%$ flour basis) and RS2 ( $10 \mathrm{~g} \%$ to $30 \mathrm{~g} \%$ flour basis) contents selected for the experimental design are shown in Figure 1.

The ratio of resistant potato starch type 2 (RS2)-Zinc (Zn) blends: 1 15:0.2, 2 15:0.28, 3 25:0.2, 4 25:0.28, CP 20:0.24, 5 20:0.16, 6 20:0.32, 7 10:0.24, 8 30:0.24, (Control) 0:0. Levels: RS2 (g\% f.b.) and Zn (mg\% f.b.); f.b. flour base.

\subsection{Dough formulation}

The doughs were made according to the methods of Salinas et al. (2012) with some modifications. Each flour mixture consisted of wheat flour ( $400 \mathrm{~g}$ ), $2 \mathrm{~g} \% \mathrm{NaCl}$ (w/w, wheat flour basis, $8 \mathrm{~g}$ ), the amount of Zn and RS2 in the design (Figure 1), and the optimum quantity of water established in Mixolab assays, water absorption $\left(\mathrm{W}_{\text {abs }}, \%\right)$. The ingredients were mixed at $90 \mathrm{rpm}$ in a small dough mixer (HM740, Qingdao Hanshang Electric Appliance Co., Ltd., Qingdao, China) according to the development time (DT) of Mixolab. The final dough temperature was $23-25^{\circ} \mathrm{C}$. The dough was made into a spherical ball of $10 \mathrm{~g}$, placed at $25^{\circ} \mathrm{C}$ for $15 \mathrm{~min}$ and covered with a film to prevent moisture loss. Ten groups of doughs with central composite design and control dough (without $\mathrm{Zn}$ and RS) were analyzed.

\subsection{Flour kneading properties}

According to the modified Constant Flour Weight (Variable Dough Weight) procedure AACC 54-21.01 (American Association of Cereal Chemists, 2000a), a Mixolab (Mixolab2, Chopin Technology, Inc., France) experiment was conducted on wheat flour with different proportions of RS2 and Zn and the control group to analyze the stirring resistance of dough at $30 \pm 0.2{ }^{\circ} \mathrm{C}$. Improvements include the addition of $\mathrm{NaCl}(2 \mathrm{~g} \%)$ to wheat flour and premixing, as described by Arp et al. (2017).

\subsection{Pasting properties}

The pasting properties were analyzed according to the methods of Jia et al. (2019). The pasting properties of the samples were determined using a rapid viscosity analyzer (RVA4500, Perten Instrument, Australia NSW). The pasting temperature, peak viscosity, through viscosity, final viscosity, breakdown, setback and peak time of flour were determined.

\subsection{Texture analysis of dough samples}

According to the Witek et al. (2020) method, a TA-XT Plus Texture Analyzer (Stable Microsystems, London, UK) was used to measure the texture characteristics. The P36R probe (diameter of $10 \mathrm{~mm}$ ) was used at a pretest speed of $2 \mathrm{~mm} / \mathrm{s}$, test speed of $1 \mathrm{~mm} / \mathrm{s}$, post-test speed of $1 \mathrm{~mm} / \mathrm{s}$, strain of $40 \%$, and interval time of $5 \mathrm{~s}$. For each formulation, a total of 30 dough pieces from three independent dough samples were assessed.

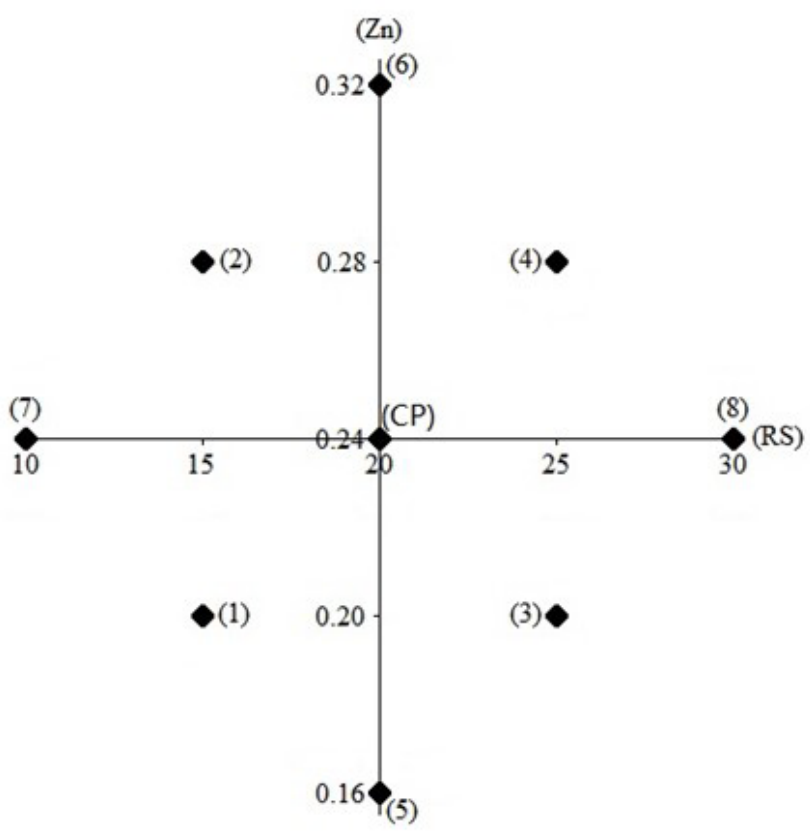

Figure 1. Experimental central composite design. 


\subsection{Dough moisture content}

The moisture content of the dough was determined as the weight difference of the dough before and after drying at $135^{\circ} \mathrm{C}$ for 2 hours in a thermostatic drying chamber (CMD-20X, Shanghai Langxuan Experimental Equipment Co., Ltd, Shanghai, China) according to AACC method 44-19 (American Association of Cereal Chemists, 2000b).

\subsection{LF-NMR}

According to the method of Meng et al. (2021b), the CPMG (Carr-Purcell-Meiboom-Gill) pulse sequence was used to test the transverse relaxation curve by an NMI20-040V-I NMR analyzer (Suzhou Newman Analytical Instruments Co. Ltd., Suzhou, China), and the spin-spin relaxation time $\left(\mathrm{T}_{2}\right)$ was analyzed. The measurement was repeated twice for each sample.

\subsection{Scanning electron microscopy (SEM)}

According to the method of Meng et al. (2021a), dough images $(1500 \times)$ were observed with a Quanta 200 scanning electron microscope (Fei Co., Ltd., USA).

\subsection{Statistical analysis}

The experiment was repeated three times, and the results are expressed as the mean \pm standard deviation. One-way ANOVA and Fisher LSD tests for the determination of significantly different means at a level of 0.05 were performed using the SPSS 17.0 software package (SPSS Inc., Chicago, USA). Origin 9.0 software was used for drawing.

\section{Results and discussion}

\subsection{Flour kneading properties}

Table 1 lists the thermomechanical parameters of the dough samples. The $\mathrm{W}_{\mathrm{abs}}(\%)$ of mixed dough decreased compared with that of the control. With the increase in the RS2 and Zn contents, the $\mathrm{W}_{\mathrm{abs}}$ of dough was reduced. The effect of RS2 on flour was more significant $(p<0.05)$ than that of $\mathrm{Zn}$. It may be that the replacement of wheat flour by high-content RS2 results in the dilution of the protein content in flour and the decrease of water retention. Overall, the stability time of the mixed dough in the kneading stage (except for groups 4 and 8) was longer than that of the control; that is, the dough strength of the mixed dough except for groups $4(0.28 \mathrm{mg} \%$ and $25 \mathrm{~g} \% \mathrm{RS} 2)$ and $8(0.24 \mathrm{mg} \%$ and $30 \mathrm{~g} \% \mathrm{RS})$ was enhanced, and the dough had a good ability to resist fermentation. The stabilization time (Stb) decreased with increasing RS2, indicating that the dough strength decreased with increasing RS2. The dough stabilization time decreased when the RS2 content was larger, and the dough stabilization time increased when the RS2 content was under $25 \mathrm{~g} \%$. RS2 diluted gluten protein to a certain extent, reduced the content of gluten-forming components in dough, and affected the formation and expansion of the gluten network. The stability time of group 7 (0.24 mg\% Zn and $10 \mathrm{~g} \% \mathrm{RS} 2)$ mixed dough was the longest, reaching $10.5 \mathrm{~min}$, and the dough had the best kneading resistance. Group 8 had the shortest stabilization time.

During the heating process, the $\mathrm{C}_{2}$ value of mixed dough decreased significantly compared with that of the control, and the addition of $\mathrm{Zn}$ and RS2 could lead to an increase in dough strength. The increase in $\mathrm{Zn}$ content will lead to an increase in the degree of weakening of the dough, resulting in the weakening of the dough strength, and the dough is more prone to rheological changes. RS2 has the opposite effect on the dough. Group 8 had the lowest weakening value, and the dough had the largest gluten force during the heating process. Group $2(0.28 \mathrm{mg} \% \mathrm{Zn}$ and $15 \mathrm{~g} \% \mathrm{RS} 2$ ) had the highest weakening value in mixed dough, and the dough was most prone to rheological changes.

The higher the value of $\mathrm{C}_{1}-\mathrm{C}_{2}$, the worse the protein quality (Ozturk et al., 2008). Compared with the control, the degree of weakening of the dough of the other groups increased, and the protein quality decreased. With increasing RS2 content, the $\mathrm{C}_{1}-\mathrm{C}_{2}$ value increased, and the resistance of the protein to mechanical stirring decreased. In group 4 , the protein quality was the worst, and the processed products were more difficult to shape. Group 7 mixed dough has the best protein quality. The starch pasting properties of the $\mathrm{C}_{3}$ and $\mathrm{C}_{3}-\mathrm{C}_{2}$ groups were significantly higher than that of the blank group except for groups 4,5 and 8 . The maximum viscosity was found in group 2 , and the

Table 1. Mixolab characteristics of dough prepared wheat flour-RS-Zn blends.

\begin{tabular}{ccccccccccccccccc}
\hline $\begin{array}{c}\text { Dough } \\
\text { Sample }\end{array}$ & $\begin{array}{c}\mathrm{RS} 2 \\
(\mathrm{~g} \%)\end{array}$ & $\begin{array}{c}\mathrm{Zn} \\
(\mathrm{mg} \%)\end{array}$ & $\begin{array}{c}\text { Wabs } \\
(\%)\end{array}$ & $\begin{array}{c}\mathrm{Stb} \\
(\mathrm{min})\end{array}$ & $\begin{array}{c}\mathrm{C}_{1} \\
(\mathrm{~N} \cdot \mathrm{m})\end{array}$ & $\begin{array}{c}\mathrm{C}_{2} \\
(\mathrm{~N} \cdot \mathrm{m})\end{array}$ & $\begin{array}{c}\mathrm{C}_{3} \\
(\mathrm{~N} \cdot \mathrm{m})\end{array}$ & $\begin{array}{c}\mathrm{C}_{4} \\
(\mathrm{~N} \cdot \mathrm{m})\end{array}$ & $\begin{array}{c}\mathrm{C}_{5} \\
(\mathrm{~N} \cdot \mathrm{m})\end{array}$ & $\begin{array}{c}\mathrm{C}_{1}-\mathrm{C}_{2} \\
(\mathrm{~N} \cdot \mathrm{m})\end{array}$ & $\begin{array}{c}\mathrm{C}_{3}-\mathrm{C}_{2} \\
(\mathrm{~N} \cdot \mathrm{m})\end{array}$ & $\begin{array}{c}\mathrm{C}_{3}-\mathrm{C}_{4} \\
(\mathrm{~N} \cdot \mathrm{m})\end{array}$ & $\begin{array}{c}\mathrm{C}_{5}-\mathrm{C}_{4} \\
(\mathrm{~N} \cdot \mathrm{m})\end{array}$ \\
\hline 1 & 15 & 0.2 & $62.0 \pm 0.5 \mathrm{~b}$ & $10.0 \pm 1.3 \mathrm{ab}$ & $1.06 \pm 0.03 \mathrm{c}$ & $0.45 \pm 0.01 \mathrm{c}$ & $1.94 \pm 0.14 \mathrm{~b}$ & $1.88 \pm 0.12 \mathrm{c}$ & $3.37 \pm 0.35 \mathrm{c}$ & $0.61 \pm 0.04 \mathrm{~d}$ & $1.49 \pm 0.03 \mathrm{ab}$ & $0.06 \pm 0.01 \mathrm{ab}$ & $1.49 \pm 0.06 \mathrm{~cd}$ \\
2 & 15 & 0.28 & $60.2 \pm 0.1 \mathrm{c}$ & $10.3 \pm 0.2 \mathrm{a}$ & $1.11 \pm 0.05 \mathrm{a}$ & $0.49 \pm 0.02 \mathrm{~b}$ & $2.01 \pm 0.06 \mathrm{a}$ & $1.97 \pm 0.11 \mathrm{~b}$ & $3.60 \pm 0.27 \mathrm{a}$ & $0.62 \pm 0.02 \mathrm{~cd}$ & $1.52 \pm 0.03 \mathrm{a}$ & $0.04 \pm 0.01 \mathrm{~b}$ & $1.63 \pm 0.07 \mathrm{a}$ \\
3 & 25 & 0.2 & $60.0 \pm 0.2 \mathrm{c}$ & $8.9 \pm 0.5 \mathrm{c}$ & $1.05 \pm 0.04 \mathrm{~d}$ & $0.41 \pm 0.04 \mathrm{~d}$ & $1.93 \pm 0.15 \mathrm{~b}$ & $1.86 \pm 0.09 \mathrm{~d}$ & $3.34 \pm 0.43 \mathrm{~cd}$ & $0.64 \pm 0.04 \mathrm{c}$ & $1.51 \pm 0.02 \mathrm{ab}$ & $0.06 \pm 0.03 \mathrm{ab}$ & $1.48 \pm 0.02 \mathrm{~d}$ \\
4 & 25 & 0.28 & $59.5 \pm 0.3 \mathrm{~d}$ & $7.3 \pm 0.8 \mathrm{~d}$ & $1.11 \pm 0.05 \mathrm{a}$ & $0.44 \pm 0.08 \mathrm{~cd}$ & $1.76 \pm 0.06 \mathrm{~d}$ & $1.99 \pm 0.14 \mathrm{~b}$ & $3.45 \pm 0.18 \mathrm{bc}$ & $0.68 \pm 0.01 \mathrm{a}$ & $1.32 \pm 0.09 \mathrm{c}$ & $-0.23 \pm 0.01 \mathrm{~d}$ & $1.46 \pm 0.03 \mathrm{e}$ \\
$\mathrm{CP}$ & 20 & 0.24 & $60.1 \pm 0.3 \mathrm{c}$ & $10.0 \pm 0.6 \mathrm{ab}$ & $1.05 \pm 0.02 \mathrm{~cd}$ & $0.44 \pm 0.05 \mathrm{~cd}$ & $1.95 \pm 0.05 \mathrm{~b}$ & $1.89 \pm 0.08 \mathrm{c}$ & $3.51 \pm 0.27 \mathrm{~b}$ & $0.61 \pm 0.04 \mathrm{~d}$ & $1.50 \pm 0.04 \mathrm{ab}$ & $0.06 \pm 0.02 \mathrm{ab}$ & $1.62 \pm 0.11 \mathrm{a}$ \\
5 & 20 & 0.16 & $60.5 \pm 0.1 \mathrm{c}$ & $9.5 \pm 0.2 \mathrm{~b}$ & $1.06 \pm 0.02 \mathrm{c}$ & $0.43 \pm 0.06 \mathrm{~cd}$ & $1.75 \pm 0.19 \mathrm{~d}$ & $1.91 \pm 0.10 \mathrm{c}$ & $3.32 \pm 0.34 \mathrm{~cd}$ & $0.63 \pm 0.03 \mathrm{~cd}$ & $1.32 \pm 0.01 \mathrm{c}$ & $-0.16 \pm 0.03 \mathrm{c}$ & $1.41 \pm 0.08 \mathrm{f}$ \\
6 & 20 & 0.32 & $59.5 \pm 0.3 \mathrm{~d}$ & $9.7 \pm 1.6 \mathrm{~b}$ & $1.10 \pm 0.07 \mathrm{~b}$ & $0.45 \pm 0.05 \mathrm{c}$ & $1.97 \pm 0.06 \mathrm{~b}$ & $1.92 \pm 0.12 \mathrm{c}$ & $3.50 \pm 0.25 \mathrm{~b}$ & $0.64 \pm 0.05 \mathrm{c}$ & $1.51 \pm 0.04 \mathrm{ab}$ & $0.05 \pm 0.01 \mathrm{ab}$ & $1.58 \pm 0.04 \mathrm{~b}$ \\
7 & 10 & 0.24 & $60.6 \pm 0.6 \mathrm{c}$ & $10.5 \pm 0.2 \mathrm{a}$ & $1.09 \pm 0.08 \mathrm{bc}$ & $0.48 \pm 0.03 \mathrm{bc}$ & $1.93 \pm 0.03 \mathrm{~b}$ & $1.86 \pm 0.06 \mathrm{~d}$ & $3.37 \pm 0.19 \mathrm{c}$ & $0.61 \pm 0.02 \mathrm{~d}$ & $1.46 \pm 0.05 \mathrm{~b}$ & $0.06 \pm 0.02 \mathrm{ab}$ & $1.51 \pm 0.05 \mathrm{c}$ \\
8 & 30 & 0.24 & $59.5 \pm 0.2 \mathrm{~d}$ & $5.8 \pm 0.4 \mathrm{e}$ & $1.06 \pm 0.06 \mathrm{c}$ & $0.40 \pm 0.08 \mathrm{~d}$ & $1.71 \pm 0.10 \mathrm{e}$ & $2.03 \pm 0.04 \mathrm{a}$ & $3.42 \pm 0.15 \mathrm{c}$ & $0.66 \pm 0.05 \mathrm{~b}$ & $1.31 \pm 0.09 \mathrm{c}$ & $-0.32 \pm 0.03 \mathrm{e}$ & $1.39 \pm 0.06 \mathrm{~g}$ \\
Control & 0 & 0 & $65.0 \pm 0.4 \mathrm{a}$ & $7.9 \pm 0.7 \mathrm{~d}$ & $1.08 \pm 0.07 \mathrm{bc}$ & $0.51 \pm 0.01 \mathrm{a}$ & $1.84 \pm 0.08 \mathrm{c}$ & $1.74 \pm 0.07 \mathrm{e}$ & $3.06 \pm 0.21 \mathrm{e}$ & $0.56 \pm 0.01 \mathrm{e}$ & $1.33 \pm 0.08 \mathrm{c}$ & $0.10 \pm 0.01 \mathrm{a}$ & $1.31 \pm 0.02 \mathrm{~h}$ \\
\hline
\end{tabular}

Note: Different letters in the same column indicate significant differences ( $<<0.05)$. Wabs, water absorption; Stb, stability. Ingredients: zine (Zn) and resistant potato starch type 2 (RS2); CP, central point (three replicates); Control, control dough (without zine and resistant starch); $\mathrm{C}_{1}$, the maximum torque when kneading dough; $\mathrm{C}_{2}$, the torque during mechanical force and heating; $\mathrm{C}_{3}$, the torque up to the maximum gelatinization viscosity; $\mathrm{C}_{4}$, the torque when starch gelatinization reaches thermal stability; $\mathrm{C}_{5}$, the torque of the starch regeneration during cooling; $\mathrm{C}_{1}-\mathrm{C}_{2}$, the weakening property of protein; $\mathrm{C}_{3}-\mathrm{C}_{2}$, the starch gelatinization properties; $\mathrm{C}_{3}-\mathrm{C}_{4}$, the thermal stability of starch gelatinization; $\mathrm{C}_{5}-\mathrm{C}_{4}$, the retrogradation characteristics of starch. 
minimum viscosity was found in group 8 . The $\mathrm{C}_{4}$ value of mixed dough increased and the $\mathrm{C}_{3}-\mathrm{C}_{4}$ value decreased, indicating that the addition of $\mathrm{Zn}$ and RS2 enhanced the thermal stability of starch in dough, and the thermal stability of groups 4 and 8 was better. $\mathrm{C}_{5}$ and $\mathrm{C}_{5}-\mathrm{C}_{4}$ indicated that the addition of RS2 and $\mathrm{Zn}$ made the dough starch easy to retrogradate, which enhanced the dough antiaging, mainly because the amylose in RS starch was rearranged, leading to the dough be easily retrogradated. The antiaging performance of group 2 was the best, and the value $\left(\mathrm{C}_{5}-\mathrm{C}_{4}\right)$ of group 8 was lower than those of the other groups.

\subsection{Pasting properties}

The viscosity of starch changed after gelatinization, which was related to the expansion and rupture of starch granules (Zavareze et al., 2010). The through viscosity, final viscosity and pasting temperature of wheat flour with RS2 and Zn addition increased significantly $(p<0.05)$ (Table 2$)$. The through viscosity and pasting temperature are proportional to the RS2. During cooling, starch molecules, especially between amylose molecules, undergo retrogradation or rearrangement, resulting in increased viscosity of starch molecules and the formation of starch gel (Chi et al., 2019). The final viscosity represents the gelatinization ability of the system, which is related to the content of amylose (Liang \& King, 2003). The final viscosity of the mixed powder with RS2 and Zn increased, indicating that the molecular aggregation of amylose increased. The increase in the RS content was inversely proportional to the final viscosity of the flour, i.e., the more RS2 there was, the less aggregation of amylose molecules. It is possible that a large amount of amylose in RS2 is stable, does not easily retrogradate and decompose, and reduces the flour viscosity.

The regeneration value represents the regeneration trend and dehydration shrinkage capacity of cooked starch during the cooling process, which is closely related to the regeneration rate of gelatinized starch and is also related to the amylose content (Wang et al., 2014). A lower regenerative value (group 8 and CP) indicated that RS2 and Zn had the potential to hinder the regeneration process via hydrogen bonds that blocked the intermolecular binding of amylose (Zhang et al., 2019). The retrogradation values of the other groups except group 8 and $\mathrm{CP}$ were higher than those of the control group. The possible reason was that the addition of RS2 and Zn changed the proportion of amylose/ amylopectin in the mixed flour and that the recrystallization properties of starch changed (Ee et al., 2020).

\subsection{Texture analysis of dough samples}

Figure 2a shows that the addition of RS2 and Zn significantly increased the hardness of the dough compared with the control group $(p<0.05)$. The hardness of the dough increased significantly with increasing Zn content under constant RS2 addition $(p<0.05)$. This may be due to the ability of RS2 to form gels and structures (Peressini \& Sensidoni, 2009), resulting in decreased water absorption and increased hardness of the dough. $\mathrm{Zn}$ increases this effect by acting as a dough enhancer. This behavior is enhanced when $\mathrm{Zn}$ recombines the gluten network due to divalent cations, resulting in increased hardness, increased elasticity, and a more uniform matrix (Salinas et al., 2012). The maximum hardness of dough was obtained at RS2 $15 \mathrm{~g} \%$ and Zn $0.28 \mathrm{mg} \%$ (group 2). The dough hardness values of RS2 $10 \mathrm{~g} \%$ and $\mathrm{Zn} 0.24 \mathrm{mg} \%$ (group 7) and RS2 20 g\% and Zn 0.16 mg\% (group 5) had little difference from that of the control.

In Figure $2 \mathrm{~b}$, the adhesiveness represents the energy needed to overcome the attraction between food surfaces and surfaces of other substances. The adhesiveness of the dough increased with the Zn content at a constant RS2 value. When RS2 was $15 \mathrm{~g} \%$ and $\mathrm{Zn}$ was $0.2 \mathrm{mg} \%$ (group 1), the adhesiveness was the lowest. The adhesiveness of the other groups increased significantly $(p<0.05)$. The adhesiveness was the highest when RS2 was $25 \mathrm{~g} \%$ and $\mathrm{Zn}$ was $0.28 \mathrm{mg} \%$ (group 4).

Springiness indicates the rate at which the deformed dough returns to its original state when extrusion is removed. Compared with the hardness, the elasticity has a similar trend. Under the constant addition of RS2, the elasticity increases with increasing $\mathrm{Zn}$. The springiness of dough decreased with increasing RS2 content in dough with the same Zn content. Doughs with $30 \mathrm{~g} \%$ RS2 and $0.24 \mathrm{mg} \% \mathrm{Zn}$ (group 8) had the minimum elasticity, group 2 (RS2: $15 \mathrm{~g} \%$; Zn: $0.28 \mathrm{mg} \%$ ) had the highest

Table 2. Pasting properties of dough prepared wheat flour-RS-Zn blends.

\begin{tabular}{|c|c|c|c|c|c|c|c|c|c|}
\hline $\begin{array}{l}\text { Dough } \\
\text { Sample }\end{array}$ & RS2 (g\%) & $\begin{array}{c}\mathrm{Zn} \\
(\mathrm{mg} \%)\end{array}$ & $\mathrm{PV}(\mathrm{cP})$ & $\mathrm{TV}(\mathrm{cP})$ & $\mathrm{BD}(\mathrm{cP})$ & $\mathrm{FV}(\mathrm{cP})$ & $\mathrm{SB}(\mathrm{cP})$ & $\mathrm{Pt}(\mathrm{min})$ & $\mathrm{PT}\left({ }^{\circ} \mathrm{C}\right)$ \\
\hline 1 & 15 & 0.2 & $3894 \pm 46 a$ & $2467 \pm 24 a$ & $1427 \pm 19 c$ & $4097 \pm 56 \mathrm{ab}$ & $1630 \pm 37 \mathrm{ab}$ & $6.20 \pm 0.01 c$ & $71.15 \pm 0.72 c$ \\
\hline 2 & 15 & 0.28 & $3895 \pm 37 a$ & $2486 \pm 29 a$ & $1409 \pm 23 c$ & $4129 \pm 66 a$ & $1643 \pm 48 \mathrm{ab}$ & $6.27 \pm 0.03 b$ & $71.85 \pm 0.34 c$ \\
\hline 3 & 25 & 0.2 & $3646 \pm 74 c$ & $2405 \pm 24 \mathrm{ab}$ & $1241 \pm 10 \mathrm{~d}$ & $4083 \pm 59 \mathrm{ab}$ & $1678 \pm 39 \mathrm{a}$ & $6.27 \pm 0.02 b$ & $78.05 \pm 0.22 \mathrm{ab}$ \\
\hline 4 & 25 & 0.28 & $3378 \pm 28 \mathrm{e}$ & $2049 \pm 25 d$ & $1329 \pm 15 c d$ & $3735 \pm 74 c$ & $1686 \pm 49 a$ & $5.93 \pm 0.01 d$ & $76.80 \pm 0.54 b$ \\
\hline $\mathrm{CP}$ & 20 & 0.24 & $3810 \pm 48 \mathrm{ab}$ & $1986 \pm 23 \mathrm{de}$ & $1824 \pm 21 \mathrm{a}$ & $1992 \pm 83 d$ & $6 \pm 1 \mathrm{e}$ & $6.20 \pm 0.03 c$ & $77.70 \pm 0.36 b$ \\
\hline 5 & 20 & 0.16 & $3243 \pm 58 \mathrm{f}$ & $2067 \pm 26 \mathrm{~cd}$ & $1176 \pm 17 \mathrm{~d}$ & $3607 \pm 78 c$ & $1540 \pm 26 \mathrm{bc}$ & $6.20 \pm 0.02 c$ & $78.50 \pm 0.85 a$ \\
\hline 6 & 20 & 0.32 & $3750 \pm 35 b$ & $2406 \pm 18 \mathrm{ab}$ & $1344 \pm 11 \mathrm{~cd}$ & $4100 \pm 63 a$ & $1694 \pm 28 \mathrm{a}$ & $6.27 \pm 0.02 b$ & $77.75 \pm 0.32 b$ \\
\hline 7 & 10 & 0.24 & $3447 \pm 89$ de & $2266 \pm 23 c$ & $1181 \pm 9 d$ & $3845 \pm 56 c$ & $1579 \pm 49 b c$ & $6.33 \pm 0.01 \mathrm{a}$ & $71.85 \pm 0.63 c$ \\
\hline 8 & 30 & 0.24 & $3652 \pm 74 c$ & $1950 \pm 15 \mathrm{e}$ & $1702 \pm 18 b$ & $1956 \pm 61 d$ & $6 \pm 2 e$ & $6.20 \pm 0.03 c$ & $78.85 \pm 0.29 a$ \\
\hline Control & 0 & 0 & $3536 \pm 39 d$ & $1905 \pm 23 \mathrm{e}$ & $1631 \pm 12 b$ & $1943 \pm 70 \mathrm{~d}$ & $38 \pm 3 \mathrm{~d}$ & $6.33 \pm 0.01 \mathrm{a}$ & $68.65 \pm 0.43 \mathrm{~d}$ \\
\hline
\end{tabular}

Note: Different letters in the same column indicate significant difference ( $p<0.05)$. PV, peak viscosity; TV, Through Viscosity; BD, breakdown; FV, final viscosity; SB, setback; Pt, Pasting

time; PT, Pasting Temperature; Ingredients: zine ( $\mathrm{Zn}$ ) and resistant potato starch type 2 (RS2); CP, central point (three replicates); Control, control dough (without zine and resistant starch). 
dough elasticity, and the CP group (RS2: 20\%; Zn: $0.24 \mathrm{mg} \%$ ) had the same elasticity as the control (Figure 2c).

Cohesiveness is a parameter of the binding force within the sample morphology. Both RS2 and Zn reduce the cohesiveness of dough (Figure 2d). Doughs with the greatest hardness and springiness (group 2) had the lowest internal cohesiveness, indicating that increased hardness and springiness would interfere with the bonding of dough particles.

Ingredients: zine (Zn) and resistant potato starch type 2 (RS); a hardness, $b$ adhesiveness, $\mathrm{c}$ springiness, and $\mathrm{d}$ cohesiveness. Different letters indicate significant differences $(\mathrm{p}<0.05)$.

\subsection{LF-NMR}

Changes in the moisture content of dough are shown in Table 3. The addition of RS2 and $\mathrm{Zn}$ to the dough led to a decrease in the dough moisture content $(p<0.05)$ because the low water holdup of RS2 itself reduced the water holdup and water absorption of the dough, leading to an increase in the dough moisture content. The moisture content of dough was inversely proportional to the addition of RS2 and Zn. Comparing Table 3, it was found that $\mathrm{Zn}$ had little effect on the change in the dough moisture content. When the $\mathrm{Zn}$ content was the same and the RS2 addition increased from $10 \mathrm{~g} \%$ to $20 \mathrm{~g} \%$, the greatest effect was seen on the dough moisture content. The moisture content of the control group was $44.21 \%$. With the addition of $\mathrm{Zn}$ and RS, the moisture content of dough gradually decreased from $43.61 \%$ (dough 7: $0.24 \mathrm{mg} \% \mathrm{Zn}$ and $10 \mathrm{~g} \% \mathrm{RS} 2$ ) to $42.26 \%$ (dough 4: $0.28 \mathrm{mg} \% \mathrm{Zn}$ and $25 \mathrm{~g} \% \mathrm{RS} 2$ ).
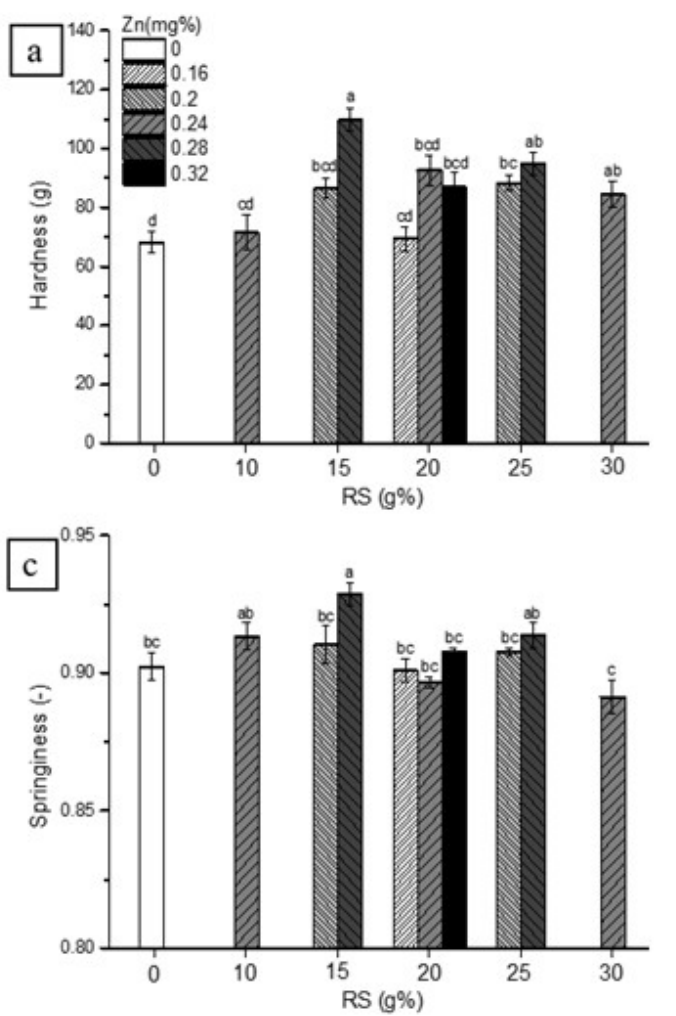

As seen from Table 3, each test group has three relaxation times, representing the three forms of water in the sample. The length of the transverse relaxation time can reflect the tightness of water binding with other components (Jiang et al., 2020). $T_{21}$ denotes deep bound water, primarily water that binds tightly to starch or gluten proteins. $\mathrm{T}_{22}$ represents weakly bound water, whose fluidity is between deep bound water and free water, and this portion of water is bound between proteins, starch and other macromolecules. $\mathrm{T}_{23}$ stands for free water (Zhou et al., 2013). As shown in Table 3, the peak of $T_{23}$ is the main peak, and its signal amplitude accounts for approximately $80 \%$ of the total signal. This result indicated that the main form of water in dough with perfect gluten formation was free water.

As shown in Table 3, there were differences in the moisture form and distribution of wheat flour dough. $\mathrm{T}_{21}(0.61 \mathrm{~ms})$, $A_{21}(6.30 \%)$ and their signal amplitude in group 8 were significantly higher than those in other groups, and their relative proton density $\mathrm{A}_{23}$ was significantly lower than those in other groups $(p<0.05)$. Different RS2 and Zn additions had no significant effect on $\mathrm{T}_{22}, \mathrm{~T}_{23}$ and $\mathrm{A}_{22}(p<0.05)$ (Table 3$)$. In the control, $\mathrm{T}_{23}(48.10 \mathrm{~ms}), \mathrm{A}_{23}(79.05 \%)$ and the signal amplitude were the largest. The results showed that the water flow in the blank group was the strongest, and the water flow in the mixed dough of group 8 was the weakest. The combination of water and other components was closer, which might be due to the increase in the RS2 content, resulting in a closer combination of water and starch. Table 3 shows that RS2 is inversely proportional to $A_{23}$. The difference in the water status of wheat flour dough may be caused by the difference in starch properties, and RS2 itself
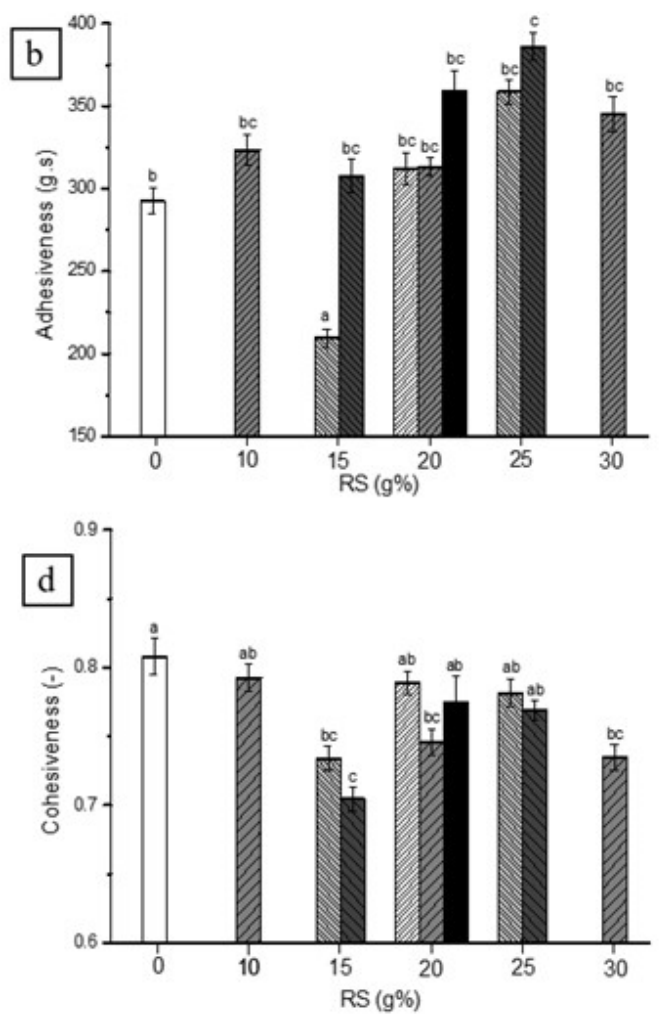

Figure 2. Texture parameters of dough prepared with wheat flour-RS-Zn blends. 
Table 3. Relaxation time (ms) and relative proton density (\%) of dough prepared wheat flour-RS-Zn blends.

\begin{tabular}{cccccccccc}
\hline $\begin{array}{c}\text { Dough } \\
\text { Sample }\end{array}$ & $\mathrm{RS} 2(\mathrm{~g} \%)$ & $\mathrm{Zn}(\mathrm{mg} \%)$ & $\mathrm{M}_{\mathrm{cont}}(\%)$ & $\mathrm{T}_{21}(\mathrm{~ms})$ & $\mathrm{T}_{22}(\mathrm{~ms})$ & $\mathrm{T}_{23}(\mathrm{~ms})$ & $\mathrm{A}_{21}(\%)$ & $\mathrm{A}_{22}(\%)$ & $\mathrm{A}_{23}(\%)$ \\
\hline 1 & 15 & 0.2 & $43.29 \pm 0.04 \mathrm{bc}$ & $0.15 \pm 0.05 \mathrm{~d}$ & $3.68 \pm 0.27 \mathrm{a}$ & $47.38 \pm 4.52 \mathrm{a}$ & $0.37 \pm 0.36 \mathrm{c}$ & $23.10 \pm 1.53 \mathrm{a}$ & $76.53 \pm 1.25 \mathrm{ab}$ \\
2 & 15 & 0.28 & $42.93 \pm 0.12 \mathrm{c}$ & $0.32 \pm 0.05 \mathrm{c}$ & $3.61 \pm 0.13 \mathrm{a}$ & $45.13 \pm 0.32 \mathrm{a}$ & $0.28 \pm 0.01 \mathrm{c}$ & $22.72 \pm 0.79 \mathrm{a}$ & $76.97 \pm 0.92 \mathrm{ab}$ \\
3 & 25 & 0.2 & $43.27 \pm 0.05 \mathrm{bc}$ & $0.40 \pm 0.11 \mathrm{bc}$ & $3.45 \pm 0.67 \mathrm{a}$ & $45.27 \pm 0.92 \mathrm{a}$ & $4.88 \pm 2.10 \mathrm{ab}$ & $20.05 \pm 1.55 \mathrm{a}$ & $75.00 \pm 3.18 \mathrm{ab}$ \\
4 & 25 & 0.28 & $42.26 \pm 0.07 \mathrm{~d}$ & $0.32 \pm 0.05 \mathrm{c}$ & $3.82 \pm 0.35 \mathrm{a}$ & $44.90 \pm 0.40 \mathrm{a}$ & $0.86 \pm 0.53 \mathrm{bc}$ & $22.92 \pm 0.45 \mathrm{a}$ & $76.42 \pm 1.11 \mathrm{ab}$ \\
$\mathrm{CP}$ & 20 & 0.24 & $42.67 \pm 0.09 \mathrm{~cd}$ & $0.27 \pm 0.14 \mathrm{~cd}$ & $3.41 \pm 0.16 \mathrm{a}$ & $45.33 \pm 0.35 \mathrm{a}$ & $1.06 \pm 1.12 \mathrm{bc}$ & $21.42 \pm 1.16 \mathrm{a}$ & $76.31 \pm 1.82 \mathrm{ab}$ \\
5 & 20 & 0.16 & $42.69 \pm 0.07 \mathrm{~cd}$ & $0.31 \pm 0.11 \mathrm{c}$ & $3.30 \pm 0.89 \mathrm{a}$ & $45.43 \pm 1.17 \mathrm{a}$ & $1.45 \pm 0.43 \mathrm{bc}$ & $20.44 \pm 3.43 \mathrm{a}$ & $78.49 \pm 4.39 \mathrm{a}$ \\
6 & 20 & 0.32 & $42.45 \pm 0.03 \mathrm{~d}$ & $0.36 \pm 0.13 \mathrm{bc}$ & $3.64 \pm 0.15 \mathrm{a}$ & $45.13 \pm 0.46 \mathrm{a}$ & $3.23 \pm 2.04 \mathrm{abc}$ & $22.56 \pm 1.55 \mathrm{a}$ & $75.09 \pm 1.18 \mathrm{ab}$ \\
7 & 10 & 0.24 & $43.61 \pm 0.05 \mathrm{~b}$ & $0.49 \pm 0.01 \mathrm{ab}$ & $3.74 \pm 0.52 \mathrm{a}$ & $45.10 \pm 0.65 \mathrm{a}$ & $1.73 \pm 2.69 \mathrm{bc}$ & $21.32 \pm 2.18 \mathrm{a}$ & $76.95 \pm 4.48 \mathrm{ab}$ \\
8 & 30 & 0.24 & $42.41 \pm 0.13 \mathrm{~d}$ & $0.61 \pm 0.05 \mathrm{a}$ & $3.64 \pm 0.26 \mathrm{a}$ & $44.90 \pm 0.40 \mathrm{a}$ & $6.30 \pm 5.29 \mathrm{a}$ & $21.45 \pm 2.13 \mathrm{a}$ & $72.25 \pm 4.32 \mathrm{~b}$ \\
Control & 0 & 0 & $44.21 \pm 0.03 \mathrm{a}$ & $0.25 \pm 0.07 \mathrm{~cd}$ & $3.47 \pm 0.16 \mathrm{a}$ & $48.10 \pm 0.35 \mathrm{a}$ & $1.18 \pm 0.11 \mathrm{bc}$ & $19.77 \pm 1.16 \mathrm{a}$ & $79.05 \pm 1.69 \mathrm{a}$ \\
\hline
\end{tabular}

Note: The values were mean \pm standard error $(\mathrm{n}=3)$. Different letters in the same column indicate significant difference $(p<0.05)$. $\mathrm{M}_{\text {cont }}$, moisture content; $\mathrm{T}_{21}$, relaxation time of bound water; $\mathrm{T}_{22}$, relaxation time of immobile water; $\mathrm{T}_{23}$, relaxation time of free water; $\mathrm{A}_{21}$, relative proton density of bound water; $\mathrm{A}_{22}$, relative proton density of immobile water; $\mathrm{A}_{23}$, relative proton density of free water; Ingredients: zine (Zn) and resistant potato starch type 2 (RS2); CP, central point (three replicates); Control, control dough (without zine and resistant starch).
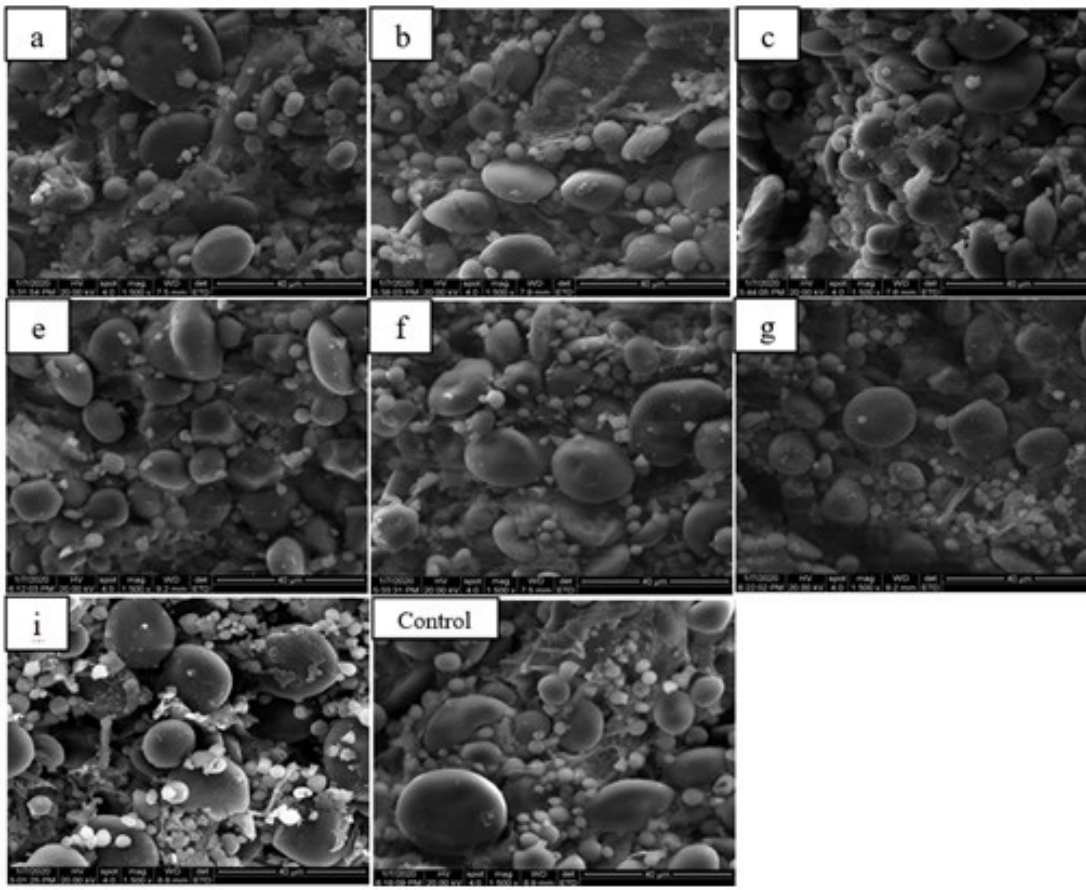

Figure 3. SEM of dough.

Note: a dough 1 (0.2 mg\% Zn and 15 g\% RS2); b dough 2 (0.28 mg\% Zn and 15 g\% RS2); c dough 3 (0.2 mg\% Zn and 25 g\% RS2); d dough 4 $(0.28 \mathrm{mg} \% \mathrm{Zn}$ and $25 \mathrm{~g} \%$ RS2); e dough CP (0.24 mg\% Zn and $20 \mathrm{~g} \%$ RS2); f dough 5 (0.16 mg\% Zn and 20 g\% RS2); g dough 6 (0.32 mg\% Zn and $20 \mathrm{~g} \%$ RS2); h dough 7 (0.24 mg\% Zn and $10 \mathrm{~g} \%$ RS2) and i dough 8 (0.24 mg\% Zn and $30 \mathrm{~g} \%$ RS2). Magnification, $\times 1500$.

has low water holding capacity, meaning that more RS2 in the dough results in less free water. The more $\mathrm{Zn}$ in the dough, the more the relaxation time $\mathrm{T}_{23}$ of peak 3 decreases, but $\mathrm{Zn}$ has little effect on it. Doona \& Baik (2007) found that water and starch played a decisive role in water mobility in dough. This is consistent with the NMR results of our samples. The specific reasons and mechanism need further research and confirmation.

\subsection{Scanning electron microscopy (SEM)}

The formation of dough is not a simple physical process. From the perspective of microstructure, dough promotes the interaction between gliadin and glutenin during stirring and standing and forms the network structure of gluten. There are complex changes in the valence bonds between gluten protein peptide chains. The microstructure of dough determines its macroscopic elongation and viscoelasticity.

Figure 3 is a 1500 times magnification microphotograph of the dough. The structure of the dough includes a gluten protein matrix, aggregated small starch granules and independent large starch granules. As reported by Rueda et al. (2017), the gap between larger starch granules was filled with smaller starch granules to form a closer structure. As shown in Figure 3, compared with the 
control, the gluten protein matrix supplemented with different proportions of RS2 and Zn exhibited fracture, deformation and contraction, showing a fragmented structure. The starch particles were more dispersed and had more starch particles on the surface, and some starch particles appeared sunken or even seriously cracked on the surface. Due to the effect of gluten dilution, the decrease in high concentrations of small starch granules and gluten protein causes an obstruction of network development (Arp et al., 2018).

With increasing RS2 content, the fracture of the gluten network deepened, and gluten protein fragments increased, which adhered to the surface of starch and resulted in the unsmooth appearance of starch. The number of free starch granules and irregular voids increased, indicating that the increase in the RS2 content deepened the breakdown of the gluten network structure, and the combination between starch granules and gluten protein was looser. With increasing $\mathrm{Zn}$ content, the structure of the gluten network of mixed dough was rough and uneven, and the structure of the gluten protein network was looser. The degree of binding between starch particles and gluten protein decreased, and more starch particles were exposed outside the network structure. However, $\mathrm{Zn}$ had an inhibitory effect on the sag rupture of starch particles. In the dough with RS2 and $\mathrm{Zn}$ addition, the microstructure of Figure $3 \mathrm{~h}$ was the best. Most of the starch particles were evenly wrapped in the gluten protein matrix. The protein and starch were closely bound together, the degree of protein breakdown was less, and the surface of starch particles was smoother than that of the dough with other addition ratios. In Figure $3 i$ the protein was the most broken, the content was less, the number of holes was more, the combination of starch and protein was loosest, and the starch was seriously broken. RS2 has a greater impact than $\mathrm{Zn}$ on the dough structure.

\section{Conclusion}

In the presence of a higher RS2 content, the stabilization time of dough becomes shorter, and the moisture content is lower. The higher the RS2 content, the lower the free water content and the smaller the molecular mobility of the dough. RS2 has a destructive effect on the network structure and starch granules of dough protein, resulting in looser binding between starch and protein. Zn acts as a dough enhancer in the presence of RS2. This behavior was enhanced when $\mathrm{Zn}$ recombined the gluten network due to divalent cations, resulting in a dough with increased hardness, elasticity, and a more uniform matrix. With the increase in RS2 and Zn addition, the proportion of gluten content decreased, which not only reduced the water absorption of dough but also increased the hardness and springiness properties of dough. These effects are particularly evident at higher $\mathrm{Zn}$ levels. However, the addition of RS2 and Zn increased the dough strength and enhanced the anti-retrogradation and thermal stability of starch in dough. The conformation and particular flexibility of the binding of protein-RS2-Zn-water ultimately determines the degree of water binding in dough. Therefore, if the final spatial conformation of the protein is modified by RS2-Zn-carbonate, it will produce different substrates with different rigidities/flexibilities and water binding capacities, thus having different rheological properties. Taken together, the addition of RS2 $(10 \mathrm{~g} \%)$ and $\mathrm{Zn}(0.24 \mathrm{mg} \%)$ could render a dough with satisfactory rheological properties, hydration and microstructural characteristics.

\section{Acknowledgement}

This work was financed by Central government guiding local scientific and technological development projects (No. 2021), the Program of Xinxiang Major Scientific and Technological Project (No. ZD2020003); and Science and Technology Projects in Henan Province (grant number 19A550007).

\section{References}

American Association of Cereal Chemists - AACC. (2000a). Farinograph method for flour 54-21.01. In AACC International approved methods (pp. 1-7). Saint Paul: AACC International.

American Association of Cereal Chemists - AACC. (2000b). Approved methods of the American association of cereal chemists (10th ed.). Saint Paul: AACC International.

Arp, C. G., Correa, M. J., \& Ferrero, C. (2018). Rheological and microstructural characterization of wheat dough formulated with high levels of resistant starch. Food and Bioprocess Technology, 11(6), 1149-1163. http://dx.doi.org/10.1007/s11947-018-2083-8.

Arp, C. G., Correa, M. J., Zuleta, A., \& Ferrero, C. (2017). Techno functional properties of wheat flour-resistant starch mixtures applied to bread making. International Journal of Food Science \& Technology, 52(2), 550-558. http://dx.doi.org/10.1111/ijfs.13311.

Chi, C. D., Li, X. X., Zhang, Y. P., Chen, L., Xie, F. W., Li, L., \& Bai, G. H. (2019). Modulating the invitro digestibility and predicted glycemic index of rice starch gels by complexation with gallic acid. Food Hydrocolloids, 89, 821-828. http://dx.doi.org/10.1016/j. foodhyd.2018.11.016.

Doona, C. J., \& Baik, M. Y. (2007). Molecular mobility in model dough systems studied by time-domain nuclear magnetic resonance spectroscopy. Journal of Cereal Science, 45(3), 257-262. http://dx.doi. org/10.1016/j.jcs.2006.07.015.

Dupuis, J. H., Liu, Q., \& Yada, R. Y. (2014). Methodologies for increasing the resistant starch content of food starches: a review. Comprehensive Reviews in Food Science and Food Safety, 13(6), 1219-1234. http:// dx.doi.org/10.1111/1541-4337.12104.

Ee, K. Y., Eng, M. K., \& Lee, M. L. (2020). Physicochemical, thermal and rheological properties of commercial wheat flours and corresponding starches. Food Science and Technology, 40(Suppl. 1), 51-59. http:// dx.doi.org/10.1590/fst.39718.

Englyst, H. N., Kingman, S. M., \& Cummings, J. H. (1992). Classification and measurement of nutritionally important starch fractions. European Journal of Clinical Nutrition, 46(2, Suppl .2), S33-50. PMid:1330528.

Fuentes-Zaragoza, E., Riquelme-Navarrete, M. J. J., Sanchez-Zapata, E., \& Perez-Alvarez, J. A. (2010). Resistant starch as functional ingre-dient: a review. Food Research International, 43(4), 931-942. http://dx.doi.org/10.1016/j.foodres.2010.02.004.

Jia, T., Zeng, J., Gao, H. Y., Jiang, J. K., Zhao, J. X., Su, T. C., \& Sun, J. L. (2019). Effect of pectin on properties of potato starch after dry heat treatment. Tropical Journal of Pharmaceutical Research, 18(7), 1375-1384. http://dx.doi.org/10.4314/tjpr.v18i7.2.

Jiang, J., Zeng, J., Gao, H. Y., Zhang, L., Wang, F., Su, T. C., Xiang, F. J., \& Li, G. L. (2020). Effect of low temperature on the aging characteristics of a potato starch gel. International Journal of 
Biological Macromolecules, 150, 519-527. http://dx.doi.org/10.1016/j. ijbiomac.2020.02.077. PMid:32057878.

Khuri, A. I., \& Cornell, J. A. (1996). Response surfaces: designs and analyses (2nd ed.). New York: Marcel Dekker.

Liang, X., \& King, J. M. (2003). Pasting and crystalline property differences of commercial and isolated rice starch with added amino acids. Journal of Food Science, 68(3), 832-836. http://dx.doi. org/10.1111/j.1365-2621.2003.tb08251.x.

Majdoub, N., Kaab, L. B. B., Vieira, A. I., Faleiro, M. L., El-Guendouz, S., \& Miguel, M. G. (2020). Zn treatment effects on biological potential of fennel bulbs as affected by in vitro digestion process. Food Science and Technology, 40(Suppl. 1), 60-67. http://dx.doi. org/10.1590/fst.34918.

Meng, K., Gao, H. Y., Zeng, J., Li, G. L., \& Su, T. C. (2021a). Effect of subfreezing storage on the quality and shelf life of frozen fermented dough. Journal of Food Processing and Preservation, 45(3), 1-12. http://dx.doi.org/10.1111/jfpp.15249.

Meng, K., Gao, H. Y., Zeng, J., Zhao, J., Qin, Y., Li, G., \& Su, T. (2021b). Rheological and microstructural characterization of wheat dough formulated with konjac glucomannan. Journal of the Science of Food and Agriculture, 101(10), 4373-4379. http://dx.doi.org/10.1002/ jsfa.11078. PMid:33417243.

Mocchegiani, E., Giacconi, R., Cipriano, C., Costarelli, L., Muti, E., Tesei, S., Giuli, C., Papa, R., Marcellini, F., Mariani, E., Rink, L., Herbein, G., Varin, A., Fulop, T., Monti, D., Jajte, J., Dedoussis, G., Gonos, E. S., Trougakos, I. P., \& Malavolta, M. (2007). Zinc, metallothioneins, and longevity: effect of zinc supplementation: zincage study. Annals of the New York Academy of Sciences, 1119(1), 129-146. http://dx.doi. org/10.1196/annals.1404.030. PMid:18056962.

Nugent, A. P. (2005). Health properties of resistant starch. Nutrition Bulletin, 30(1), 27-54. http://dx.doi.org/10.1111/j.1467-3010.2005.00481.x.

Ozturk, S., Kahraman, K., Tiftik, B., \& Koksel, H. (2008). Predicting the cookie quality of flours by using Mixolab. European Food Research and Technology, 227(5), 1549-1554. http://dx.doi.org/10.1007/ s00217-008-0879-x.

Peressini, D., \& Sensidoni, A. (2009). Effect of soluble dietary fibre addition on rheological and breadmaking properties of wheat doughs. Journal of Cereal Science, 49(2), 190-201. http://dx.doi. org/10.1016/j.jcs.2008.09.007.

Poudel, R. R., Bhusal, Y., Tharu, B., \& Kafle, N. K. (2017). Role of zinc in insulin regulation and diabetes. Journal of Social Health and Diabetes, 5(2), 83-87. http://dx.doi.org/10.1055/s-0038-1676241.

Ranasinghe, P., Wathurapatha, W. S., Ishara, M. H., Jayawardana, R., Galappatthy, P., Katulanda, P., \& Constantine, G. R. (2015). Effects of Zinc supplementation on serum lipids: a systematic review and meta-analysis. Nutrition \& Metabolism, 12, 26. http://dx.doi. org/10.1186/s12986-015-0023-4. PMid:26244049.

Rueda, M. M., Auscher, M. C., Fulchiron, R., Perie, T., Martin, G., Sonntag, P., \& Cassagnau, P. (2017). Rheology and applications of highly filled polymers: a review of current understanding. Progress in Polymer Science, 66, 22-53. http://dx.doi.org/10.1016/j. progpolymsci.2016.12.007.

Sajilata, M. G., Singhal, R. S., \& Kulkarni, P. R. (2006). Resistant starch-a review. Comprehensive Reviews in Food Science and Food Safety, 5(1), 1-17. http://dx.doi.org/10.1111/j.1541-4337.2006.tb00076.x. PMid:33412740.

Salinas, M. V., Zuleta, A., Ronayne, P., \& Puppo, M. C. (2012). Wheat flour enriched with calcium and inulin: a study of hydration and rheological properties of dough. Food and Bioprocess Technology, 5(8), 3129-3141. http://dx.doi.org/10.1007/s11947-011-0691-7.

Wang, N., Warkentin, T. D., Vandenberg, B., \& Bing, D. J. (2014). Physicochemical properties of starches from various pea and lentil varieties, and characteristics of their noodles prepared by high temperature extrusion. Food Research International, 55, 119-127. http://dx.doi.org/10.1016/j.foodres.2013.10.043.

Witek, M., Maciejaszek, I., \& Surowka, K. (2020). Impact of enrichment with egg constituents on water status in gluten-free rice pasta-nuclear magnetic resonance and thermogravimetric approach. Food Chemistry, 304, 125417. http://dx.doi.org/10.1016/j.foodchem.2019.125417. PMid:31493705.

World Health Organization (2002). Quantifying selected major risks to health. In World Health Report 2002: reducing risks to health noncommunicable diseases (pp. 47-97). Geneva: World Health Organization.

Yonekura, L., \& Suzuki, H. (2005). Effects of dietary zinc levels, phyticacid and resistant starch on zinc bioavailability in rats. European Journal of Nutrition, 44(6), 384-391. http://dx.doi.org/10.1007/s00394-0040540-9. PMid:16151969.

Zavareze, E. R., Storck, C. R., Castro, L. A. S., Schirmera, M. A., \& Dias, A. R. G. (2010). Effect of heat-moisture treatment on rice starch of varying amylose content. Food Chemistry, 121(2), 358-365. http:// dx.doi.org/10.1016/j.foodchem.2009.12.036.

Zhang, Y., Li, G., Wu, Y., Yang, Z., \& Ouyang, J. (2019). Influence of amylose on the pasting and gel texture properties of chestnut starch during thermal processing. Food Chemistry, 294, 378-383. http:// dx.doi.org/10.1016/j.foodchem.2019.05.070. PMid:31126477.

Zhou, Y., Cao, H., Hou, M., Nirasawa, S., Tatsumi, E., Foster, T. J., \& Cheng, Y. Q. (2013). Effect of konjac glucomannan on physical and sensory properties of noodles made from low-protein wheat flour. Food Research International, 51(2), 879-885. http://dx.doi. org/10.1016/j.foodres.2013.02.002. 